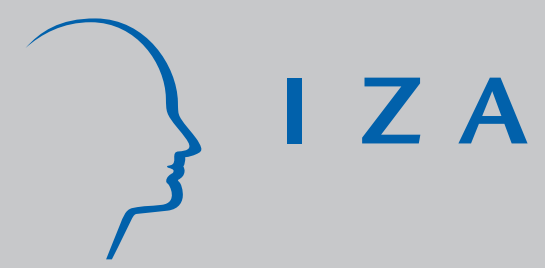

IZA DP No. 8919

United, Yet Apart? A Note on Persistent Labour Market Differences between Western and Eastern Germany

Claus Schnabel

March 2015 


\title{
United, Yet Apart? A Note on Persistent Labour Market Differences between Western and Eastern Germany
}

\author{
Claus Schnabel \\ University of Erlangen-Nürnberg \\ and IZA \\ Discussion Paper No. 8919 \\ March 2015
}

IZA

P.O. Box 7240

53072 Bonn

Germany

Phone: +49-228-3894-0

Fax: +49-228-3894-180

E-mail: iza@iza.org

Any opinions expressed here are those of the author(s) and not those of IZA. Research published in this series may include views on policy, but the institute itself takes no institutional policy positions. The IZA research network is committed to the IZA Guiding Principles of Research Integrity.

The Institute for the Study of Labor (IZA) in Bonn is a local and virtual international research center and a place of communication between science, politics and business. IZA is an independent nonprofit organization supported by Deutsche Post Foundation. The center is associated with the University of Bonn and offers a stimulating research environment through its international network, workshops and conferences, data service, project support, research visits and doctoral program. IZA engages in (i) original and internationally competitive research in all fields of labor economics, (ii) development of policy concepts, and (iii) dissemination of research results and concepts to the interested public.

IZA Discussion Papers often represent preliminary work and are circulated to encourage discussion. Citation of such a paper should account for its provisional character. A revised version may be available directly from the author. 


\title{
ABSTRACT
}

\section{United, Yet Apart? A Note on Persistent Labour Market Differences between Western and Eastern Germany*}

\begin{abstract}
Comparing aggregate statistics and surveying selected empirical studies, this paper shows that the characteristics and results of labour markets in eastern and western Germany have become quite similar in some respects but still differ markedly in others even 25 years after unification. Whereas no substantial differences can be detected in firms' labour demand decisions and in employees' representation via works councils or trade unions, both parts of the country are somewhat apart concerning labour supply behaviour, labour productivity, wages, and bargaining coverage, and they still exhibit substantially different rates of unemployment. These differences may reflect observable and unobservable characteristics of economic actors as well as differences in behaviour, norms, and individuals' attitudes.
\end{abstract}

JEL Classification: J01, J20, J30, J50, P27

Keywords: $\quad$ labour market disparities, German unification, transition, Germany

Corresponding author:

Claus Schnabel

Friedrich-Alexander-Universität Erlangen-Nürnberg

Chair of Labour and Regional Economics

Lange Gasse 20

90403 Nürnberg

Germany

E-mail: claus.schnabel@fau.de

\footnotetext{
* The author would like to thank Tina Hinz, Boris Hirsch, Regina T. Riphahn, Joachim Wagner and two anonymous referees for helpful comments and suggestions.
} 
"Now we are in a situation where what belongs together is growing together"

Willy Brandt (10 November, 1989)

\section{Introduction}

On 3 October, 1990 West and East Germany were re-united after having been separated by the Iron Curtain for more than 40 years. In the 1990 election campaign Chancellor Helmut Kohl promised that unification would create "flourishing landscapes" in the east and that East Germany would soon achieve living standards comparable to those in West Germany. 25 years later there is still an economic and social divide between the eastern and western parts of Germany, with a sizeable economic disadvantage of eastern Germany. A quick look at some macroeconomic indicators in Table 1 reveals that there has been some convergence between western and eastern Germany, in particular during the 1990s, but that the catch-up process has slowed down markedly so that in most cases full equalisation has not been achieved yet. Table 1 reports the average level of an indicator reached in eastern Germany as a percentage of the average western German level. For instance, in 2013 nominal GDP per capita in the five federal states of eastern Germany amounted to 67 percent of the average level in western Germany (excluding Berlin), compared to just 33 percent in 1991. Labour productivity and labour cost in eastern Germany reached about three quarters of the western German level in 2013, and the capital stock per employee was 13 percent lower than in the west. Whereas the rate of self-employment has fully caught up to the western German level, the employment-population rate in eastern Germany has always been lower and the unemployment rate clearly higher than in western Germany.

(Table 1 about here)

The extent of and the reasons for these differences between the western and eastern parts of Germany have been documented and discussed in a number of publications, often brought out on occasion of the $20^{\text {th }}$ or $25^{\text {th }}$ anniversary of the fall of the Berlin wall (see, e.g., Paqué 2009, Röhl 2014, Brenke 2014). In a certain sense, the present paper adds to this literature by discussing the state of convergence with a specific focus on the labour market, where the west-east divide is still quite pronounced. ${ }^{1}$ However, the

\footnotetext{
${ }^{1}$ That said, this note does not aim to describe and analyse in detail the convergence process and the labour market policies that may have played a role in this context. Nor does it intend to derive policy recommendations for achieving a more rapid convergence.
} 
main contribution of this paper is to look behind the aggregate labour market differences and to show that there are also differences in the behaviour of labour market actors and in the explanatory power of our economic models in western and eastern Germany. Even though eastern Germany is a very special case among post-communist countries, the present paper can also been seen as a modest contribution to the literature on transition economics and labour markets in transition (as reviewed by Lehmann and Muravyev 2013).

The purpose of this paper is to survey economic studies that analyse the determinants of labour supply and demand, wages, wage setting and industrial relations, and to investigate whether these determinants are usually the same and play a similar role in western and eastern Germany. Put differently, are the economic models describing individuals' and firms' behaviour in various fields equally applicable to western and eastern Germany and do they have similar explanatory power in both parts of Germany? Is it reasonable to treat united Germany as a (more or less) homogeneous entity when doing empirical labour market research or is it advisable to analyse western and eastern German labour markets separately even 25 years after unification? How can we explain the fact that quite a few labour market studies published in recent years only use data for western Germany while neglecting the eastern part of the country?

The paper is structured as follows: Section 2 provides a brief comparison of key labour market indicators for western and eastern Germany, demonstrating that even a quarter of a century after German unification there are still marked differences between east and west. A number of selected studies on labour supply, labour demand, wages, wage setting, and industrial relations are analysed in section 3 with respect to their results for western and eastern Germany, again finding substantial differences in some important fields of the labour market. Section 4 discusses why the results of many studies differ between western and eastern Germany and how researchers handle (or should handle) these differences. I argue that even 25 years after unification it makes sense to analyse western and eastern Germany separately in various fields of labour market research and that one should not expect to obtain similar results for both parts of the country.

\section{A comparison of key labour market indicators in western and eastern Germany}

Table 2 presents a number of key labour market indicators for western and eastern Germany in 2013 , collected from various sources and comprising both administrative 
data and representative survey data. ${ }^{2}$ Starting with labour supply, the labour force participation rate of men is similar in western and eastern Germany, but the participation rate of women is almost five percentage points higher in the east. Working hours also differ somewhat between both parts of the country: average working hours per week laid down in collective bargaining agreements are 1.6 hours higher in eastern Germany, whereas actual working hours of full-time employees (as reported in the German SocioEconomic Panel, GSOEP) are quite similar in both parts of Germany. Substantial differences in terms of the utilization of the labour force potential can be found when looking at the rates of employment and unemployment. The employment rate, defined as the percentage of the population aged 15-64 that has a job, is higher for men in western than in eastern Germany, whereas the reverse is the case for women. Although the east-west disparity in unemployment has been reduced over time (see Figure 1), the unemployment rate is still much higher in eastern than in western Germany. The structure of unemployment and underemployment also differs considerably between both parts of the country (for details, see Fuchs et al. 2014).

(Table 2 about here)

(Figure 1 about here)

Although differences in average labour productivity should not be over-interpreted due to composition and price effects (for details, see Brenke 2014), it may be noted that eastern Germany also lags behind western Germany when looking at this indicator. Whereas average labour productivity, defined as GDP per hour worked, amounted to 49.59 Euros per hour in western Germany in 2013, the corresponding value for eastern Germany was only 35.15 , that is almost 30 percent lower. Accordingly, average gross hourly wages were only 18.03 Euros in eastern Germany, compared to 24.70 Euros in the west.

Striking differences can also be detected when looking at the process of wage formation. Whereas in western Germany 32 percent of establishments and 60 percent of employees are covered by a collective bargaining agreement (either at sectoral or at firm level), in eastern Germany this is true only for 20 percent of establishments and 47

\footnotetext{
${ }^{2}$ The comparison of western and eastern German averages of course neglects that there are further, interesting differences between German regions at the level of federal states or districts, also within western and eastern Germany (as reported in the Microcensus and the National Accounts at state level by the Federal Statistical Office, and in the labour market statistics by the Federal Employment Agency). However, since the Kohl promise of rapid convergence, politics, and public opinion in Germany have always focused on the east-west comparison, and most of the empirical studies discussed in section 3 also apply this distinction.
} 
percent of employees. Differences are smaller concerning another important institution of industrial relations in Germany, namely the extent of workplace codetermination. Both in western and eastern Germany, works councils exist in one out of ten establishments with five or more employees, but the proportion of employees working in establishments with a works council is somewhat higher in western Germany. Finally, union density is somewhat lower in the eastern part of the country.

This brief and crude comparison indicates that in many respects the labour market situation in eastern Germany is different from that in western Germany, and that labour market outcomes are often worse. In principle, these disparities can result from different levels in the determinants of labour market activities (such as the age structure of the population, firm size, industry structure, bargaining coverage), and this is also the sort of explanation most often given for the differences showing up in aggregate statistics (see, e.g., Brenke 2014, Röhl 2014, Fuchs et al. 2014). However, observed disparities could also result from individuals or firms in eastern Germany behaving differently given similar conditions and incentives as in the west (i.e. under a ceteris paribus condition). It will therefore be interesting to see what multivariate analyses of labour supply, labour demand, wages etc. tell us when analysing western and eastern Germany either jointly or in separate sub-samples.

\section{Empirical studies comparing western and eastern Germany}

In the following, I will discuss the results of selected studies for Germany that analyse key labour market variables and allow a comparison of western and eastern Germany. Although these studies are the result of an extensive search in the German and international literature and on the homepages of German labour economists, I do not claim completeness and I only present selected studies that can be regarded as typical for the field investigated. I focus on five key areas of the labour market, namely labour supply, labour demand, productivity, wages, and wage setting and industrial relations. Although any selection of areas and studies is to a certain degree subjective, the five key areas chosen are most important for assessing the working of the labour markets in both parts of Germany and the state of convergence, and consequently they have attracted a lot of research. ${ }^{3}$ Since my main interest is to find out whether the labour

\footnotetext{
${ }^{3}$ Further interesting areas of labour market research not covered here are segregation (see Beblo et al 2008), personnel turnover and employment stability (see Grotheer et al. 2004, Boockmann and Steffes 2010), and east-west migration (Alm et al. 2014). Note that (mainly for the sake of brevity) I also do not
} 
markets in western and eastern Germany still differ substantially in recent years, I only discuss studies that comprise data from 2000 onwards, i.e. at least 10 years after unification. Studies that only refer to the 1990s are not included, even if they may provide interesting information on the transformation process of the eastern German labour market after unification. Although a complete survey of all studies published since 1990 and of all areas of labour market research might be interesting and fruitful, it is clearly beyond the scope of this note.

\subsection{Labour supply}

Table 2 indicates that the labour force participation rate of men has attained similar levels in both parts of Germany whereas for women this indicator of labour supply is still considerably higher in eastern than in western Germany (see also Holst and Wieber 2014). The latter difference also shows up in various empirical analyses of female labour supply and employment (labour supply of men is usually not found worth investigating).

Analysing GSOEP data from 1999 to 2002, Haan (2005) demonstrates that two major differences between married women in eastern and western Germany are the higher labour market participation rate in the east and the higher prevalence of part-time work in the west. He argues that these differences can be mainly explained by the different historical background in both parts of Germany and by the better child care system for younger children in the east. This seems plausible given that west-east differences are particularly pronounced in the group of mothers. Consistent with this finding, Kreyenfeld and Geisler (2006) show with data from the Microcensus 2002 that mothers in eastern Germany are much more likely to work full-time than those in the west. Moreover, whereas in eastern Germany married and single women with children living in the household show similar employment patterns, in western Germany married mothers are less likely to work full-time than unmarried mothers. ${ }^{4}$ A study with GSOEP data from

\footnotetext{
discuss reforms of labour market institutions (see, e.g., Fahr and Sunde 2009, Cygan-Rehm 2013) and (active) labour market policies (see, e.g., the review by Wolff and Stephan 2013), both of which often have had different impacts in western and eastern Germany. It is an open question whether the different intensity of active labour market policies in eastern and western Germany and their effects on labour supply, labour demand and wages have also contributed to the differences in economic behaviour and outcomes discussed here.

${ }^{4}$ Kreyenfeld and Geisler (2006) also present evidence from ALLBUS, the German General Social Survey, showing that there are substantial differences in the attitudes of the population towards working mothers, with western Germans much more often fearing that a young child may suffer when its mother is working.
} 
1991 to 2006 by Vogel (2009) suggests that such differences in labour supply are not confined to mothers. Generally, women in eastern Germany are less likely to work parttime than those in western Germany, and transitions from part-time into full-time employment are more often found in the eastern part of the country, whereas women in western Germany often seem to prefer part-time employment as a means to combine family and working life.

Analysing a GSOEP panel of married and cohabitating couples in the period 2000 to 2007, Haan and Wrohlich (2011) also show that female employment behaviour in eastern Germany differs substantially from that in the western part of Germany (whereas fertility rates are fairly similar). Although finding a job is more difficult in the east, employment rates of women are generally higher in the east than in the west. Eastern German women are more likely to be in regular employment whereas western German women are more often found in marginal employment (including part-time work with less than 12 hours per week). Simulating the labour supply and fertility responses to a 1 percent increase in the net income at work, Haan and Wrohlich (2011) find that in general employment rates and weekly working hours of women increase but that groups with a strong labour market attachment like women in eastern Germany change their employment behaviour only slightly. This confirms previous findings by Haan (2005) that the labour supply elasticities of married women are considerably higher in western than in eastern Germany.

Focusing on a more specific group, namely mothers, Geyer et al. (2014) report substantial differences in labour supply elasticities, with mothers in eastern Germany showing a significantly lower preference for leisure than mothers in western Germany in a sample of GSOEP waves 2001 to 2006. According to the authors, this divergence reflects the different historical and social backgrounds of the two regions and the traditionally higher labour market attachment of eastern German women. ${ }^{5}$ Also concentrating on the employment behaviour of mothers, Hanel and Riphahn (2012) find marked differences between western and eastern Germany which have partly decreased over time. Using repeated annual cross-sectional Microcensus samples for the period 1996 to 2004, the authors report that on average about 64 percent of eastern

For a more general comparison of beliefs about women's labour in both parts of Germany, see Lee et al. (2007).

${ }^{5}$ See also the descriptive analysis of GSOEP data by Holst and Wieber (2014) which shows that even in 2013 the desired and actual working hours of mothers are significantly higher in eastern than western Germany. 
but only 37 percent of western German mothers are employed to a substantial extent (i.e. working at least 20 hours per week). This difference of 27 percentage points reduces to 13-16 percentage points in multivariate analyses taking account of various personal and regional characteristics, but remains quite substantial. In a fully interacted model, Hanel and Riphahn (2012) find significantly different coefficient estimates for eastern German mothers for most covariates included (such as own, partner and family characteristics or regional indicators). In particular, at each age of the youngest child the maternal propensity to work at least 20 hours per week is significantly higher in eastern than in western Germany. Over time, this propensity declined more rapidly in eastern Germany. A closer look shows that it is only low and medium skilled eastern German mothers who changed their behaviour over time and appear to adopt western German low employment patterns. Hanel and Riphahn $(2012,171)$ conclude that "the behavioral differences between East and West German mothers declined since the early years after German unification, but persist until recently."6

\subsection{Labour demand}

In contrast to labour supply, studies on labour demand usually do not find substantial differences between western and eastern Germany. In a recent analysis covering the time period 1996 to 2010 and based on the IAB Establishment Panel, Jung (2014) shows that firms' employment adjustment process is somewhat faster (so that adjustment costs are lower) in eastern than in western Germany, but the difference is not statistically significant. This confirms the findings of previous studies by Bellmann and Pahnke (2006) and Fuchs (2010). With linked employer-employee data (LIAB 19962004), Bellmann and Pahnke (2006) further find that organisational change and restructuring have had similar (positive) employment effects in western and eastern German establishments. Analysing the relationship between employment growth, hirings and separations with IAB Establishment Panel data over the period 1993 to 2009, Bellmann et al. (2011) show that the responsiveness of separations with respect

\footnotetext{
${ }^{6}$ Marked differences between mothers in eastern and western Germany are also reported by Felfe (2012) when examining the extent to which women are willing to trade wages for non-wage job attributes in the context of maternity leave. Using data from the GSOEP and the Qualification and Career Survey, only western German mothers are found to sacrifice significant amounts of their wage in order to adjust the work schedule to their family life. This is explained by the fact that in contrast to eastern Germany there was virtually no daycare for children younger than 3 in western Germany in the observation period ranging until 2006, so that the only chance mothers with very young children had to stay in the labour market was to arrange childcare informally by working during hours when the partner or another member of the extended family was not working and could take care of the child.
} 
to employment growth is slightly smaller in western Germany, whereas there is no difference between west and east in the hirings response.

Freier and Steiner (2007) combine data from the Employment Panel of the Federal Employment Agency and the Microcensus to investigate marginal employment and the demand for heterogeneous labour in the period 1999 to 2003. They find that own-wage elasticities show the same general pattern in both parts of the country but are somewhat smaller (in absolute value) in eastern Germany. Whereas estimated own-wage elasticities for unskilled workers in full-time and in marginal employment differ substantially in western Germany, they differ little in eastern Germany. Cross-wage elasticities between skilled labour and other labour inputs are found to be of similar size in eastern and western Germany. These findings are broadly consistent with those of Jung (2014, Table 5) who shows that short- and long-term own-wage elasticities for homogeneous labour are quite similar in both parts of Germany.

In general, the characteristics and determinants of labour demand identified in these studies are alike in both parts of Germany (with the exception of the regional employment study by Fuchs (2010) where the coefficient of the wage rate proves to be insignificant in eastern Germany). This implies that firms' employment decisions are based on similar considerations - in accordance with the neoclassical theory of labour demand - in eastern and western Germany so that in terms of employer behaviour there seems to be no east-west divide.

\subsection{Labour productivity}

The vast east-west difference in average labour productivity per worker and per hour reported in Tables 1 and 2 is often said to mainly reflect compositional effects, e.g. differences between western and eastern Germany in the employment structure w.r.t. industries and qualifications, in establishment size, and in capital intensity (for critical discussions of these explanations, see Ragnitz 2007 and Brenke 2014). It is thus interesting to see that productivity differences between western and eastern Germany still show up in multivariate analyses with establishment data that take confounding factors like establishment size, industry affiliation, human capital of the workforce, capital intensity, and existence of works councils explicitly into account.

For instance, cross-sectional OLS estimations of production functions with data from the IAB Establishment Panel and the LIAB are provided by Addison et al. (2006) for the 
years 1997 to 2000 and by Schneider (2007) for the year 2003. In their samples pooling western and eastern Germany, the estimated dummy variable for eastern Germany is significantly negative, indicating that there still exists a sizeable productivity gap, and this gap proves to be larger in the service than in the manufacturing sector. Also using IAB Establishment Panel data but covering a longer time period (1998 to 2009), Müller (2013) estimates value added per employee and reports that labour productivity in eastern German establishments is about 30 percent lower, ceteris paribus (i.e. when holding a large number of control variables fixed). In contrast to these studies for united Germany, Bellmann et al. (2006) estimate translog production functions separately for western and eastern Germany in their analysis of productivity differences in the manufacturing sector in the years 1998 to 2002. They find that by and large the same factors (such as skill composition of the workforce, export share, product innovation, being a headquarter) play a significant role in explaining establishment productivity both in western and eastern Germany. However, as Bellmann et al. (2006) do not estimate a fully interacted model concerning location in eastern Germany, it remains an open question whether the coefficients of the covariates differ significantly between western and eastern German establishments.

A tentative conclusion from the extant empirical evidence is that east-west differences in measured labour productivity can neither be fully explained by different endowments (like human and physical capital, establishment size, and existence of works councils) nor by different coefficients of relevant covariates. Differences in sales prices that affect recorded (nominal) volumes of sales and value added may play a role (see Ragnitz 2007, Brenke 2014), but they are unlikely to explain the entire, persistent productivity gap. Further unobserved or unobservable heterogeneity in factors like management quality or innovative ability might be relevant but this proves to be difficult to investigate econometrically. Clearly further research is needed to explain why 25 years after unification eastern German establishments still lag so much behind their western German counterparts.

\subsection{Wages}

The productivity gap between western and eastern Germany finds a parallel in the persistent wage gap between both parts of the country. In a macroeconomic analysis for the period 1991 to 2007, Smolny (2009) looks at the interaction of wages, 
competitiveness, and the labour market situation in eastern Germany. Comparing wages in the five eastern German states to the average value of western Germany he finds a fast adjustment process that slowed down in the mid-1990s. Relative wages increased sharply in the early 1990s which lowered competitiveness of eastern German firms and led to an increase in unemployment, which in turn changed firms' and trade unions' incentives and power in the wage-setting process and dampened wage growth. According to Smolny (2009), the remaining east-west gaps in wages, unit labour costs and unemployment more or less can be interpreted as an equilibrium, and a complete convergence is not within the range of the adjustment processes implied by his empirical findings.

Analyzing the wage adjustment process with micro data from the GSOEP 1992 to 2005 and applying matching procedures, Gernandt and Pfeiffer (2008) find that 15 years after unification gross hourly wages for eastern and western German workers with similar characteristics had not completely converged (whereas the degree of wage inequality in the two regions converged). In 2005, workers who had always worked in eastern Germany received on average about 70 to 75 percent of the wages of their statistical twins from western Germany. Interestingly, eastern German workers that had migrated to the west earned 95 to 100 percent and workers commuting to western Germany received about 85 percent of the wages of their western German statistical twins.

That migrants from eastern Germany living and working in western Germany receive an income only slightly below that of similar western German employees is also found by Smolny and Kirbach (2011) when analysing GSOEP data for 1993 to 2008. Estimating earnings functions for western and eastern Germany that control for some observable determinants of monthly gross income, the authors further ask what eastern German employees would have earned if their working place had been in western rather than eastern Germany. They find that observed income differences are not due to a lower, less valuable human capital of eastern German employees but rather reflect a locational disadvantage of working in eastern Germany.

Smolny and Kirbach (2011) observe similar age-earnings profiles in both parts of the country, indicating that those factors that are important for wage determination in western Germany are also relevant in the east. In contrast, based on GSOEP data for 2002 to 2006 Orlowski and Riphahn (2009) do find some differences in age-earnings profiles between western and eastern Germany for full-time employed male workers in 
the private sector (despite a lack of precision in their estimates for eastern Germany). Although returns to tenure with the current employer are similar in eastern and western Germany, returns to general work experience are found to be significantly higher in the west (in particular for high-skilled workers), even after controlling for potential biases and composition effects. Returns to experience even differ for those birth cohorts who gathered their entire work experience after German unification, suggesting that "the type of experience earned in the East German labour market differs in quality from that earned in the West German labour market" (Orlowski and Riphahn 2009, 652).

A certain limitation of these studies based on GSOEP data is that they are not able to control for many firm characteristics that should also play a role in wage determination. Using linked employer-employee data (LIAB) for 2000 to 2007 and applying an OaxacaBlinder decomposition analysis, however, Gühne and Markwardt (2014) show that among firm characteristics it is only the different sector structure of firms that partly explains the east-west wage differential whereas other potential determinants like firm size or bargaining coverage are negligible. Concerning personal characteristics, different endowments in human capital and the structure of occupations only play a minor role. According to Gühne and Markwardt (2014), it is the lower returns to work experience in the east - already found by Orlowski and Riphahn (2009) - that make a big difference and explain a large part of the east-west wage differential. This implies that employees in eastern Germany are less able than their western German colleagues to increase their wages over the course of their working life.

Looking at wage mobility (i.e. upward or downward movements in the wage distribution of full-time employees) with administrative data (SIAB) until 2010, Riphahn and Schnitzlein (2015) find that wage mobility in eastern Germany continuously declined after unification and soon fell below western German levels. A decomposition analysis shows that whereas in eastern and western Germany most of the change in wage mobility is associated with structural shifts, i.e. with changes in correlation patterns and the relevance of unobservable factors, in eastern Germany a significant share of the total decline in wage mobility is associated with composition effects, i.e. with changes in observable factors such as job stability and employment characteristics. However, the lower wage mobility in eastern Germany in recent years is not related to the characteristics of the eastern German workforce nor to its employment relationships. Instead, it appears to be driven by east-west differences in the correlation between observable factors and wage mobility. Put differently, given observable characteristics 
yield lower wage volatility in eastern than in western Germany. Evidence for lower (upward) wage mobility in eastern Germany is also provided by Schank et al. (2009) with representative linked employer-employee data. Using bivariate probit estimations with endogenous selection in the low-wage sector and taking account of the different median wages in western and eastern Germany, they analyse to which extent full-time employees who earned low wages in 1998/99 were able to reach higher wage levels in the following years up to 2005 . They find that this probability of moving out of the lowwage sector is significantly lower in establishments in eastern Germany, ceteris paribus.

Finally, some differences between both parts of the country also seem to exist concerning the unexplained gender pay gap, i.e. the pay gap between the sexes after controlling for differences in standard wage determinants such as human capital, working hours, and establishment characteristics. Analysing three different crosssectional data sets for 2001 and 2003, Ziegler (2005) finds that the unexplained gender pay gap is somewhat lower in eastern than in western Germany. With GSOEP data for 1993 to 2008, Smolny and Kirbach (2011) also show that the gender pay gap is smaller in eastern than in western Germany and appears to have fallen over time in eastern Germany. Focusing more on establishment characteristics by analysing linked employer-employee data for 2008, Hirsch et al. (2012) confirm that the unexplained gender pay gap is somewhat lower in eastern Germany. Moreover, they point to another difference between both parts of the country: whereas in western Germany the unexplained wage gap is reduced in establishments facing strong product competition (and thus having fewer possibilities for wage discrimination), no such relationship can be detected in eastern Germany. In a cross-sectional analysis for the year 2008 Hirsch (2013) also finds a lower unexplained gender wage gap in eastern Germany (of about 2.5 percentage points) in his preferred specification with job-cell fixed effects but no substantial differences between western and eastern Germany concerning the dampening impact of female managers on the gender pay gap.

Taken together, the extant evidence indicates that wages and wage mobility of workers with similar observable characteristics still differ considerably between both parts of Germany. The reasons for the backlog in eastern German wages are not completely clear, ranging from a different valuation of human capital acquired on the eastern German labour market to an (unspecified) locational disadvantage of working in eastern Germany. Another potential explanation not investigated yet could be monopsonistic behaviour of employers who might find it easier in eastern Germany to exploit labour 
market frictions and pay lower wages to immobile employees. In addition, differences between western and eastern Germany in industrial relations and in the wage-setting process may play a role, and these differences will be discussed next.

\subsection{Wage setting and industrial relations}

Table 2 indicates that in eastern Germany a much smaller proportion of establishments and employees are covered by collective bargaining arrangements. A closer look shows that while sectoral bargaining is indeed much more prevalent in western than eastern Germany, the incidence and the introduction of bargaining agreements at establishment level is higher in eastern Germany (see Addison et al. 2010, Ellguth and Kohaut 2014). Analysing data from the IAB Establishment Panel for united Germany in 2004, Addison et al. (2013a) find that the probability of sectoral bargaining is substantially higher in western Germany whereas the probability of firm-level bargaining is higher in eastern Germany, ceteris paribus (i.e. when controlling for other determinants of bargaining coverage like establishment size, establishment age, and composition of the workforce). Using the same data set but separate subsamples of eastern and western Germany for the years 2000 to 2008, Addison et al. (2013b) report that in both parts of the country by and large the same determinants are related to establishments' probability of being covered by a collective agreement, with the notable exception that foreign ownership of the firm seems to play a different role for bargaining coverage in eastern than in western Germany. These findings are largely consistent with an earlier analysis by Schnabel et al. (2006) for sectoral and firm-level bargaining. Martensen (2014), however, finds more differences between western and eastern Germany in the determinants of various forms of wage setting in 2012 , e.g. concerning the role of product market competition and the share of workers with higher education.

More important than these differences in the incidence and the determinants of sectoral and firm-level bargaining may be fact that the share of establishments and employees not covered by any kind of collective agreement is much higher in eastern than in western Germany (see Addison et al. 2013b, Ellguth and Kohaut 2014). As being covered by collective bargaining usually goes along with higher wages (for details, see Gürtzgen 2008, Addison et al. 2014), this contributes to the backlog in wages found in eastern Germany. What is more, among those establishments covered by collective agreements the probability of paying wages above the level stipulated in the agreement 
is much lower in eastern Germany (see Jung and Schnabel 2011, Ellguth and Kohaut 2014). Interestingly, Jung and Schnabel (2011) find that whereas their economic model does a good job in explaining the probability of paying higher wages than collectively agreed in western Germany, the explanatory factors identified are of much lower relevance in eastern Germany.

In contrast to the vast differences in collective bargaining between western and eastern Germany, the extent of worker codetermination via works councils is similar in both parts of the country, even if the proportion of employees working in establishments with a works council is somewhat higher in western Germany (see Table 2). The latter difference partly reflects the fact that works councils are more often found in larger establishments (Ellguth and Kohaut 2014), and large firms are rarer in eastern Germany. Multivariate analyses indicate that, ceteris paribus, the probability of works council existence and of works council introduction is slightly higher in western Germany (see, e.g., Addison et al. 2013a), but differences are small and not always statistically significant (see also Kraft and Lang 2008, Oberfichtner 2013).

Convergence between eastern and western Germany can also be observed in another important indicator of the German industrial relations system, namely union density. Although the share of employees who are union members used to be much higher in eastern Germany after unification, it has declined more rapidly and is now even slightly lower than in western Germany (see Schnabel and Wagner 2007, Anders et al. 2015). However, even though union density is largely similar in both parts of the country, it has proved to be more difficult to identify the determinants of union membership in eastern Germany (see Schnabel and Wagner 2007, Fitzenberger et al. 2011). Interestingly, according to a decomposition analysis by Schnabel and Wagner (2007) based on ALLBUS data, differences in union density over time and between eastern and western Germany to a large degree cannot be explained by differences in the characteristics of employees. Fitzenberger et al. (2011) agree that deunionization is not mainly due to changes in the composition of the workforce, but their decomposition analysis based on GSOEP data reveals small differences between eastern and western Germany, in particular that in 2003 the composition of the workforce was more pro-union in western Germany whereas employees in eastern Germany were slightly more pro-union than their western German colleagues with similar characteristics. 
All in all, the empirical evidence concerning crucial labour market institutions and organisations is mixed. Looking at the incidence of codetermination via works councils and of union membership and at the determinants of these variables, there is not much difference anymore between eastern and western Germany. In contrast, there exists a substantial and persistent gap between both parts of the country in terms of bargaining coverage which has not been explained satisfactorily by extant studies and which may partly be path-dependent (i.e. reflecting the traditionally high commitment of western German employers and employees to cooperative industrial relations and collective agreements).

\section{Conclusions}

The comparison of aggregate statistics and the survey of selected empirical studies both have shown that the characteristics and the results of labour markets in eastern and western Germany have become quite similar in some respects but still differ markedly in others. Whereas no substantial differences can be detected in firms' labour demand decisions and in employees' representation via works councils or trade unions, both parts of the country are somewhat apart concerning labour supply behaviour, labour productivity, wages, and bargaining coverage, and they still exhibit substantially different rates of unemployment. ${ }^{7} 25$ years after German unification it is thus still doubtful to which degree Germany can be regarded as a united or single labour market. 8

Where these labour market differences between eastern and western Germany come from and why the results of similar empirical models sometimes vary in both parts of the country, is still an open question. At least four, not mutually exclusive explanations come to mind:

First, the fact that theoretically hypothesized relationships are sometimes found to be statistically significant in western but not in eastern Germany could reflect the smaller

\footnotetext{
${ }^{7}$ Note also that (according to the GSOEP) life satisfaction is still lower in eastern than in western Germany, but this gap has narrowed over time and seems not to be entirely due to labour market and income differences (see, e.g. Gerlach and Stephan 2001, Easterlin and Plagnol 2008, Priem and Schupp 2014).

${ }^{8}$ That said, some of these differences can probably not only be found between eastern and western Germany but also between northern and southern Germany or in different regions of other countries (see, e.g. the north-south divide in Italy). So the more general question is whether empirical labour market studies take sufficient account of regional variations (beyond plugging in region-fixed effects).
} 
size of the eastern German sub-sample which for purely mechanical reasons makes it more difficult to measure precisely and identify statistically significant associations. This may play a role in certain cases (in particular when using data sets with relatively small sample sizes) but surely cannot explain the bulk of different results.

Second, the economic actors in western and eastern Germany may differ in certain observable and/or unobservable characteristics. ${ }^{9}$ Although such differences (like firm size, human capital or the composition of the workforce) can partly explain the differences in some of the aggregate statistics reported in Table 2, the striking result of many east-west comparisons is that differences in some key indicators, such as labour productivity, wages or bargaining coverage, remain even after controlling for (observable) employee and firm characteristics in multivariate analyses. In some studies, this may be due to insufficient data on certain characteristics, in particular establishment characteristics, so that what we find is effect heterogeneity along an unobserved dimension (such as establishment size). In other cases, observed differences in outcomes may reflect unobservable heterogeneity of firms, employees or government agencies that cannot always be properly accounted for in empirical studies. ${ }^{10}$ This omitted variable problem implies that researchers may be on shaky ground when attempting to make policy recommendations for narrowing the (alleged) east-west divide.

Third, the behaviour and the reactions of employees and/or firms to similar circumstances may differ between western and eastern Germany, which is reflected in different coefficients estimated in multivariate analyses. A case in point is the finding reported above that labour supply elasticities of married women are considerably higher in western than in eastern Germany. Again, we cannot rule out that these observed differences are partly due to unobserved or unobservable heterogeneity of firms, employees or government agencies (including the implementation of labour market policies which have been applied more intensively in eastern Germany). ${ }^{11}$

\footnotetext{
${ }^{9}$ A variant of this argument would be that the employees (or firms) in eastern Germany are a selective group in that after unification they have not used the opportunity to move to western Germany and to benefit from the better earnings opportunities there.

${ }^{10}$ Although the institutional framework is the same in eastern and western Germany (e.g. concerning labour law and government transfers), the ways how this is put into practice could differ between both parts of the countries; unfortunately there is a lack of studies investigating this possibility.

11 Interestingly, in a rare analysis of the policy style of local employment agencies, Doerr and Kruppe (2014) find no significant east-west difference in the intensity of training voucher awards after controlling for regional and labour market characteristics.
} 
Finally, traditions, norms, social preferences and individuals' attitudes may differ between western and eastern Germany, which could result in the different behaviour of employees and firms discussed above. The striking difference in female labour supply, for instance, may be related to the fact that individuals in eastern Germany are significantly more likely to hold egalitarian sex-role attitudes than their western German counterparts, as demonstrated by Lee et al. (2007) and by Bauernschuster and Rainer (2012) with ALLBUS data ranging until 2008. Whereas these authors find no evidence for an east-west convergence in gender attitudes, other studies detect signs of a convergence process concerning people's thinking about redistribution (Alesina and Fuchs-Schündeln 2007) and institutional (but not social) trust (Rainer and Siedler 2009). ${ }^{12}$ As traditions, norms and attitudes usually only change slowly (if at all) and as convergence might at least partly be an intergenerational process, labour market differences of the sort described above may persist longer than expected by Willy Brandt (and others) in 1989.

The various east-west differences may explain why quite a few researchers use data (or show results) for western Germany only when conducting empirical labour market studies with German data. ${ }^{13}$ In most cases the authors of these studies justify this selection with a brief reference to the specific labour market situation or the long transition from a socialist to a market economy in eastern Germany, but in a few cases the authors also openly admit that their economic models have simply not worked satisfactorily in eastern Germany. What seems problematic (but happens frequently), however, is to refer to "Germany" in the title of a study that is only based on the experience of employees and/or firms in western Germany and thus does not reflect the (probably different) behaviour in the eastern part of the country. ${ }^{14}$

Looking at it the other way round, even 25 years after unification it seems advisable that empirical researchers refrain from simply using an all-German sample without carefully checking whether the observed relationships also hold in both parts of the country. In various fields of labour market research it still makes sense to analyse western and

\footnotetext{
${ }^{12}$ Using data from the GSOEP up to 2008, Heineck and Süssmuth (2013) also find that East Germans are still characterized by a persistent level of social distrust. Compared to West Germans, they now show similar risk attitudes but are less inclined to see others as cooperative.

${ }^{13}$ See, e.g., Villanueva (2007) on compensating wage differentials, Lehmer and Ludsteck (2011) on interregional migration, Blien et al. (2013) on the wage curve, Fitzenberger et al. (2013) on union wage effects, and Hirsch et al. (2014) on wage discrimination.

${ }^{14}$ This practice may reflect authors' fears that referees and editors of international journals, who might not be aware of the west-east divide in Germany, could be reluctant to accept a paper that openly admits being related to one part of a country only.
} 
eastern Germany separately, and we should not expect to obtain the same results for both parts of the country. To paraphrase Willy Brandt and to contradict him: We are not yet in a situation where what belongs together has fully grown together. 
Figure 1: Unemployment rates in western and eastern Germany (in \% of the civilian labour force in dependent employment)

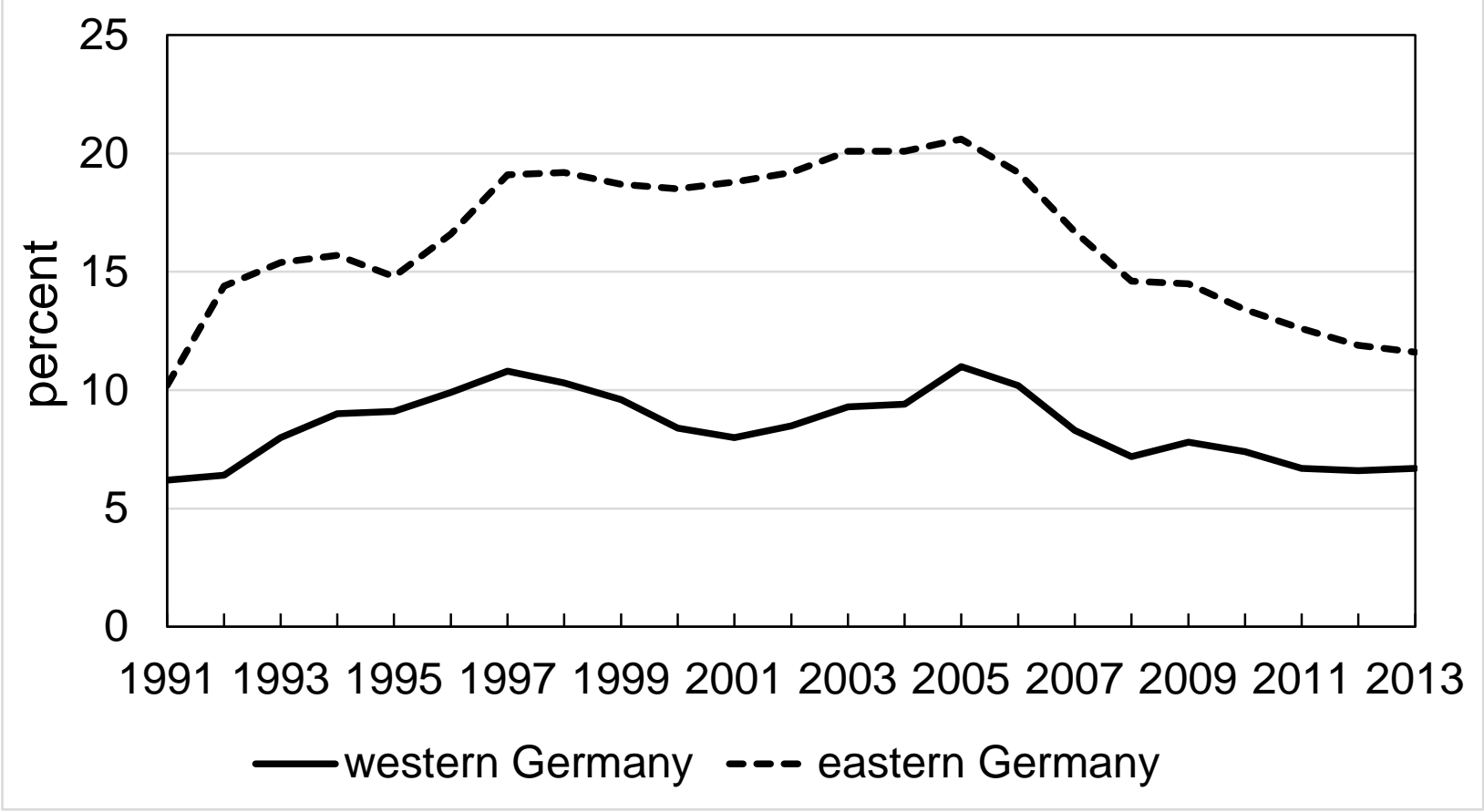

Table 1: Convergence between western and eastern Germany, 1991-2013 (values for eastern Germany expressed in percent of the value for western Germany, excluding Berlin)

\begin{tabular}{|l|c|c|c|}
\hline Indicator & 1991 & 2000 & 2013 \\
\hline Nominal GDP per capita & 33 & 60 & 67 \\
\hline Labour cost per person in dependent employment & 49 & 77 & 78 \\
\hline Productivity: real GDP per person employed & 42 & 69 & 76 \\
\hline Capital stock per person in dependent employment & 40 & 73 & 87 \\
& & & $(2010)$ \\
\hline Rate of self-employment & 50 & 84 & 106 \\
\hline Employment-population rate & 96 & 88 & 88 \\
\hline Unemployment rate & 207 & 239 & 163 \\
\hline
\end{tabular}

Source: Röhl (2014). 
Table 2: Key labour market indicators in western and eastern Germany, 2013

\begin{tabular}{|c|c|c|}
\hline Indicator & $\begin{array}{l}\text { Western } \\
\text { Germany }\end{array}$ & $\begin{array}{l}\text { Eastern } \\
\text { Germany }\end{array}$ \\
\hline $\begin{array}{l}\text { Labour force participation rate (in \% of population } \\
\text { aged 15-64) } \\
\text { - men } \\
\text { - women }\end{array}$ & $\begin{array}{l}82.3 \\
71.5\end{array}$ & $\begin{array}{l}82.3 \\
76.2\end{array}$ \\
\hline $\begin{array}{l}\text { Weekly working hours of full-time employees } \\
\text { - hours laid down in collective agreements } \\
\text { - actual working hours: men } \\
\text { - actual working hours: women }\end{array}$ & $\begin{array}{l}37.4 \\
44.3 \\
42.5\end{array}$ & $\begin{array}{l}39.0 \\
44.2 \\
43.3\end{array}$ \\
\hline $\begin{array}{l}\text { Employment rate (in \% of population aged 15-64) } \\
\text { - men } \\
\text { - women }\end{array}$ & $\begin{array}{l}78.4 \\
68.5\end{array}$ & $\begin{array}{l}74.9 \\
70.0\end{array}$ \\
\hline $\begin{array}{l}\text { Unemployment rate } \\
\text { - in \% of civilian labour force } \\
\text { - in \% of civ. labour force in dependent employment }\end{array}$ & $\begin{array}{l}6.0 \\
6.7\end{array}$ & $\begin{array}{l}10.3 \\
11.6\end{array}$ \\
\hline $\begin{array}{l}\text { Labour productivity: GDP per hour worked (in } € \text {, } \\
\text { excluding Berlin) }\end{array}$ & 49.59 & 35.15 \\
\hline Gross hourly wages (in $€$ ) & 24.70 & 18.03 \\
\hline $\begin{array}{l}\text { Bargaining coverage (sector- or plant-level collective } \\
\text { agreements) } \\
\text { - \% of establishments covered } \\
\text { - \% of employees covered }\end{array}$ & $\begin{array}{l}32 \\
60\end{array}$ & $\begin{array}{l}20 \\
47\end{array}$ \\
\hline $\begin{array}{l}\text { Presence of a works council } \\
-\% \text { of establishments } \\
\text { - \% of employees in these establishments }\end{array}$ & $\begin{array}{l}9 \\
43\end{array}$ & $\begin{array}{l}10 \\
35\end{array}$ \\
\hline $\begin{array}{l}\text { Net union density, } 2012 \text { (\% of employees being union } \\
\text { members) }\end{array}$ & 21 & 17 \\
\hline
\end{tabular}

Sources: Federal Statistical Office (Microcensus, National Accounts at state level), Federal Employment Agency, IAB Establishment Panel (Ellguth and Kohaut 2014), Federal Ministry of Labour and Social Affairs, GSOEP (Holst and Wieber 2014), ALLBUS (Anders et al. 2015), IAQ (www.sozialpolitik-aktuell.de); own calculations. 


\section{References}

Addison, J.T./Bryson, A./Teixeira, P./Pahnke, A./Bellmann, L. (2010): The State of Collective Bargaining and Worker Representation in Germany: The Erosion Continues, IZA Discussion Paper No. 5030, Bonn

Addison, J.T./Bryson, A./Teixeira, P./Pahnke, A./Bellmann, L. (2013a): The extent of collective bargaining and workplace representation: Transitions between states and their determinants. A comparative analysis of Germany and Great Britain, Scottish Journal of Political Economy 60(2), 182-209

Addison, J.T./Bryson, A./Teixeira, P./Pahnke, A. (2013b): Collective agreement status and survivability: Change and persistence in the German model, LABOUR 27(3), 288309

Addison, J.T./Schank, T./Schnabel, C.Magner, J. (2006): Works Councils in the Production Process, Schmollers Jahrbuch 126(2), 251-283

Addison, J.T./Teixeira, P./Evers, K./Bellmann, L. (2014): Indicative and Updated Estimates of the Collective Bargaining Premium in Germany, Industrial Relations 53(1), 125-157

Alesina, A./Fuchs-Schündeln, N. (2007): Good-bye Lenin (or not?): The effect of communism on people's preferences, American Economic Review 97(4), 1507-1528

Alm, B./Engel, D./Weyh, A. (2014): Does Switching to a Western German Employer Still Pay Off? An Analysis for Eastern Germany, Jahrbücher für Nationalökonomie und Statistik 234(5), 546-571

Anders, C./Biebeler, H./Lesch, H. (2015): Mitgliederentwicklung und politische Einflussnahme: Die deutschen Gewerkschaften im Aufbruch?, iw-trends 42(1), 21-36

Bauernschuster, S./Rainer, H. (2012): Political regimes and the family: how sex-role attitudes continue to differ in reunified Germany, Journal of Population Economics 25(1), 5-27

Beblo, M./Heinze, A./Wolf, E. (2008): Entwicklung der beruflichen Segregation von Männern und Frauen zwischen 1996 und 2005 - Eine Bestandsaufnahme auf betrieblicher Ebene, Zeitschrift für Arbeitsmarktforschung 41(2+3), 181-198

Bellmann, L./Ellguth, P./Möller, I. (2006): Produktivitätsunterschiede in west- und ostdeutschen Betrieben im Verarbeitenden Gewerbe, in: Bellmann, L./Ludwig, U. (eds.): Beschäftigungsanalysen mit den Daten des IAB-Betriebspanels, Beiträge zum Workshop des IAB und IWH 2005, Institut für Wirtschaftsforschung Halle, 171-192

Bellmann, L./Gerner, H.-D./Upward, R. (2011): Job and worker turnover in German establishments, IZA Discussion Paper No. 6081, Bonn

Bellmann, L./Pahnke, A. (2006): Auswirkungen organisatorischen Wandels auf die betriebliche Arbeitsnachfrage, Zeitschrift für Arbeitsmarktforschung 39(2), 201-233 
Blien, U./Dauth, W./Schank, T./Schnabel, C. (2013): The Institutional Context of an 'EmpiricalLaw': The Wage Curve under Different Regimes of Collective Bargaining, British Journal of Industrial Relations 51(1), 59-79

Boockmann, B./Steffes, S. (2010): Workers, Firms, or Institutions: What Determines Job Duration for Male Employees in Germany? Industrial and Labor Relations Review 64(1), 109-127

Brenke, K. (2014): Eastern Germany Still Playing Economic Catch-Up, DIW Economic Bulletin 4(11), 6-23

Cygan-Rehm, K. (2013): Parental leave benefit and differential fertility responses: Evidence from a German reform, BGPE Discussion Paper No. 142, Nürnberg

Doerr, A./Kruppe, T. (2014): Training Vouchers, Local Employment Agencies, and Policy Styles, Journal for Labour Market Research, online first (DOI 10.1007/s12651014-0168-z)

Easterlin, R.A./Plagnol, A.C. (2008): Life satisfaction and economic conditions in East and West Germany pre- and post-unification, Journal of Economic Behavior \& Organization 68(3-4), 433-444

Ellguth, P./Kohaut, S. (2014): Tarifbindung und betriebliche Interessenvertretung: Ergebnisse aus dem IAB-Betriebspanel 2013, WSI Mitteilungen 67(4), 286-295.

Fahr, R./Sunde, U. (2009): Did the Hartz reforms speed-up the matching process? A macro-evaluation using empirical matching functions, German Economic Review 10(3), 284-316

Felfe, C. (2012): The willingness to pay for job amenities: Evidence from mothers' return to work, Industrial and Labor Relations Review 65(2), 427-454

Fitzenberger, B./Kohn, K./Wang, Q. (2011): The erosion of union membership in Germany: determinants, densities, decompositions, Journal of Population Economics 24(1), 141-165

Fitzenberger, B./Kohn, K./Lembcke, A.C. (2013): Union density and varieties of coverage: The anatomy of union wage effects in Germany, Industrial and Labor Relations Review 66(1), 169-197

Freier, R./Steiner, V. (2007): 'Marginal Employment' and the Demand for Heterogenous Labour: Empirical Evidence from a Multi-Factor Labour Demand Model for Germany, IZA Discussion Paper No. 2577, Bonn

Fuchs, M. (2010): Determinanten regionaler Beschäftigungsentwicklung, Nürnberg.

Fuchs, M.Mesling, M./Weyh, A. (2014): Potenzialnutzung in Ostdeutschland: Eine Analyse von Angebot und Nachfrage auf dem Arbeitsmarkt (IAB-Forschungsbericht 6/2014), Nürnberg 
Gerlach, K./Stephan, G. (2001): Lebenszufriedenheit und Erwerbsstatus: Ost- und Westdeutschland im Vergleich, Mitteilungen aus der Arbeitsmarkt- und Berufsforschung 34(4), 515-529

Gernandt, J./Pfeiffer, F. (2008): Wage Convergence and Inequality after Unification: (East) Germany in Transition, ZEW Discussion Paper No. 08-22, Mannheim

Geyer, J./Haan, P.Mrohlich, K. (2014): The effects of family policy on mothers' labor supply: Combining evidence from a structural model and a natural experiment, DIW Discussion Paper No. 1366, Berlin

Grotheer, M./Struck, O./Bellmann, L./Gewiese, T. (2004): Determinanten der Beschäftigungsstabilität - Chancen und Risiken von 'Entrants' im ost-westdeutschen Vergleich, in: Struck, O./Köhler, C. (eds.): Beschäftigungsstabilität im Wandel? München, 125-156

Gühne, M./Markwardt, G. (2014): Lohnunterschiede zwischen Ost- und Westdeutschland: Neue Einsichten, ifo Dresden berichtet 3/2014, 37-44

Gürtzgen, N. (2008): Das Forschungspotenzial von Linked-Employer-Employee-Daten am Beispiel von Lohneffekten der Tarifbindung, Wirtschafts- und Sozialstatistisches Archiv 2, 223-240

Haan, P. (2005): State Dependence and Female Labor Supply in Germany: The Extensive and the Intensive Margin, DIW Discussion Paper No. 538, Berlin

Haan, P.Mrohlich, K. (2011): Can child care policy encourage employment and fertility? Evidence from a structural model, Labour Economics 18, 498-512

Hanel, B./Riphahn, R.T. (2012): The employment of mothers - Recent developments and their determinants in East and West Germany, Jahrbücher für Nationalökonomie und Statistik 232(2), 146-176

Heineck, G./Süssmuth, B. (2013): A Different Look at Lenin's Legacy: Trust, Risk, Fairness and Cooperativeness in the two Germanies, Journal of Comparative Economics 41(3), 789-803.

Hirsch, B. (2013): The impact of female managers on the gender pay gap: Evidence from linked employer-employee data for Germany, Economics Letters 119(3), 348-350

Hirsch, B./Oberfichtner, M./Schnabel, C. (2012): Do women benefit from competitive markets? Product market competition and the gender pay gap in Germany, Economics Bulletin 32(2), 1618-1624

Hirsch, B./Oberfichtner, M./Schnabel, C. (2014): The Levelling Effect of Product Market Competition on Gender Wage Discrimination, IZA Journal of Labor Economics 3:19

Holst, E.Mieber, A. (2014): Eastern Germany Ahead in Employment of Women, DIW Economic Bulletin 4(11), 33-41 
Jung, S. (2014): Employment Adjustment in German Firms, Journal for Labour Market Research 47(1+2), 83-106

Jung, S./Schnabel, C. (2011): Paying More than Necessary? The Wage Cushion in Germany, LABOUR 25(2), 182-197

Kraft, K./Lang, J. (2008): The Causes and Consequences of Adopting a Works Council, Jahrbücher für Nationalökonomie und Statistik 228(5+6), 512-532

Kreyenfeld, M./Geisler, E. (2006): Müttererwerbstätigkeit in Ost- und Westdeutschland, Zeitschrift für Familienforschung 18(3), 333-360

Lee, K. S./Alwin, D. F./Tufis, P. A. (2007): Beliefs about Women's Labour in the Reunified Germany, 1991-2004, European Sociological Review 23(4), 487-503

Lehmann, H./Muravyev, A. (2013): Labor Markets and Labor Market Institutions in Transition Economies, in: Hare, P./Turley, G. (eds.): Handbook of the Economics and Political Economy of Transition, Abingdon, 350-362

Lehmer, F./Ludsteck, J. (2011): The returns to job mobility and inter-regional migration: Evidence from Germany, Papers in Regional Science 90(3), 549-572

Martensen, F. (2014): Adverse Effects of Competition and Rents on Collective Bargaining Status - Evidence from Germany, Konstanz Working Paper 2014-15

Müller, S. (2013): Works Councils and Labour Productivity: Looking beyond the Mean, British Journal of Industrial Relations, online first (DOI: 10.1111/bjir.12037)

Oberfichtner, M. (2013): Works council introductions: Do they reflect workers' voice? Discussion Paper No. 83, Lehrstuhl für Arbeitsmarkt- und Regionalpolitik, University of Erlangen-Nürnberg

Orlowski, R./Riphahn, R.T. (2009): The East German wage structure after transition, Economics of Transition 17(4), 629-659

Paqué, K.-H. (2009): Die Bilanz: Eine wirtschaftliche Analyse der deutschen Einheit, München

Priem, M./Schupp, J. (2014): Everyone Happy - Living Standards in Germany 25 Years after Reunification, DIW Economic Bulletin 4(11), 65-71

Ragnitz, J. (2007): Explaining the East German Productivity Gap -The Role of Human Capital, Kiel Working Papers No. 1310, Kiel Institute for the World Economy

Rainer, H./Siedler, T. (2009): Does democracy foster trust? Journal of Comparative Economics 37(2), 251-269

Riphahn, R.T./Schnitzlein, D. (2015): Wage Mobility in East and West Germany, mimeo, University of Erlangen-Nürnberg 
Röhl, K.-H. (2014): 25 Jahre nach dem Mauerfall - Bilanz und Herausforderungen, iwtrends 41(3), 73-90

Schank, T./Schnabel, C./Stephani, J. (2009): Geringverdiener: Wem und wie gelingt der Aufstieg?, Jahrbücher für Nationalökonomie und Statistik 229(5), 584-614

Schnabel, C.Magner, J. (2007): The persistent decline in unionization in western and eastern Germany, 1980-2004: What can we learn from a decomposition analysis?, Industrielle Beziehungen 14(2), 118-13

Schnabel, C./Zagelmeyer, S./Kohaut, S. (2006): Collective Bargaining Structure and its Determinants: An Empirical Analysis with British and German Establishment Data, European Journal of Industrial Relations 12(2), 165-188

Schneider, L. (2007): Mit 55 zum alten Eisen? Eine Analyse des Alterseinflusses auf die Produktivität anhand des LIAB, Zeitschrift für Arbeitsmarktforschung 40(1), 77-97

Smolny, W. (2009): Wage Adjustment, Competitiveness and Unemployment - East Germany after Unification, Jahrbücher für Nationalökonomie und Statistik 229(2+3), 130-145

Smolny, W./Kirbach, M. (2011): Wage differentials between East and West Germany: are they related to the location or to the people? Applied Economics Letters 18(9), 873879

Villanueva, E. (2007): Estimating Compensating Wage Differentials Using Voluntary Job Changes: Evidence from Germany, Industrial and Labor Relations Review 60(4), 544561

Vogel, C. (2009): Teilzeitbeschäftigung - Ausmaß und Bestimmungsgründe der Erwerbsübergänge von Frauen, Zeitschrift für ArbeitsmarktForschung 42(2), 170-181

Wolff, J./Stephan, G. (2013): Subsidized work before and after the German Hartz reforms: design of major schemes, evaluation results and lessons learnt, IZA Journal of Labor Policy 2:16 (http://www.izajolp.com/content/2/1/16)

Ziegler, A. (2005): Erwerbseinkommen, in: Bothfeld, S. et al.: WSI-FrauenDatenReport 2005, Berlin, 241-306 